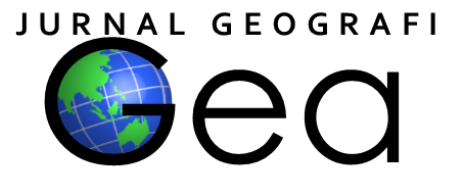

\title{
MARKETING STRATEGY OF GEOPARK CILETUH PALABUHANRATU TOURIST ATTRACTION
}

\author{
Yuli Diani Rahmawati', Agus Rahayu' ${ }^{2}$, Puspo Dewi Dirgantari ${ }^{3}$, Nandi ${ }^{4}$ \\ $1,2,{ }^{3}$ Master of Management, SPs, Universitas Pendidikan Indonesia \\ ${ }^{4}$ Department of Geography Education, Universitas Pendidikan Indonesia \\ 1yulidiani@upi.edu, ${ }^{2}$ agusrahayu@upi.edu, ${ }^{3}$ puspodewi@upi.edu, ${ }^{\mathbf{4}}$ nandi@upi.edu
}

\begin{abstract}
West Java is a province that has many mainstay tourist attractions in Indonesia. Sukabumi is a district in West Java that has one of the tourist attractions that has been inaugurated as a part of the UNESCO Global Geopark Network (UGGN) in 2018, this area opens the opportunity to become a leading destination in West Java and even nationally. The tourist attraction of the Ciletuh Palabuhanratu Geopark offers natural and cultural attractions that can be explored in geological diversity, biological diversity, and cultural diversity. The number of tourists visiting the Ciletuh Palabuhanratu Geopark Tourist Attraction has increased from 2012-2018, but in 2019 the number has decreased. This study aims to analyze the tourism marketing strategy carried out by the manager to increase the number of tourist visits to the Ciletuh Palabuhanratu Geopark. The method used is qualitative, data collection through literature study, interviews, and observation. The data obtained were analyzed descriptively. To analyze the marketing mix and strategy using a SWOT analysis, which aims to identify the strategies needed to increase tourism visits. The results showed that the marketing strategy can be done to increase the number of tourists through the SWOT approach. The SO strategy, namely the strategy of packaging attractive tourism products and services, the ST strategy through the strategy of instilling a brand image in the minds of visitors / Building a place identity (Positioning), the WO strategy, namely through the promotion strategy, the WT strategy, namely through the community empowerment strategy and building commitment and cooperation with a stakeholder.
\end{abstract}

Keywords: Marketing Strategy, SWOT Analysis, Marketing Mix, Geopark Ciletuh Palabuhanratu.

\section{INTRODUCTION}

Tourism is one of the most dynamic and fastest-growing global industries. It has been recognized as an important economic development tool that generates income and employment for developing countries (Goeldner and Ritchie, 2003). However, tourism is very vulnerable to disasters either caused by nature or by humans themselves (Zaenuri, 2014). Tourism is an industry that is very vulnerable to crises and disasters and can even be said to be very sensitive and fragile because it is very easy to be influenced by changes and events in its surroundings (Henderson, 1999: 107-120). In the current pandemic era, the tourism sector is one of the sectors most affected by social restrictions, people are required not to crowd together to prevent the spread of the virus. The Central
Statistics Agency (BPS) recorded the number of foreign tourist arrivals to Indonesia in April 2020 as 160,000 people, when compared to the number of foreign tourists in March 2020, foreign tourists decreased by 66.02 percent every month.

West Java is one of the provinces where many tourist attractions become tourist destinations in Indonesia. Sukabumi is a district that has natural beauty, where there is one tourist attraction that has been inaugurated as a part of the UNESCO Global Geopark Network (UGGN) in 2018, this area opens the opportunity to become a leading destination in West Java and even nationally.

Table 1 shows the number of tourist visits to tourist attractions in Sukabumi Regency from 2012-2019. 
Rahmawati, Rahayu, Dirgantari, Nandi. Marketing Strategy of Geopark...27

\begin{tabular}{ccc}
\hline & Table 1. Number of Tourist Visits to the Ciletuh-Palabuhanratu Geopark \\
\hline No. & Year & Number of Tourists \\
\hline 1. & 2012 & 343,910 \\
2. & 2013 & 404,622 \\
3. & 2014 & 476,373 \\
4. & 2015 & 561,122 \\
5. & 2016 & 766,191 \\
6. & 2017 & 986,149 \\
7. & 2018 & $1,175,258$ \\
8. & 2019 & 873,894 \\
\hline & amount & $5,587,519$
\end{tabular}

Source: Ciletuh Palabuhanratu Geopark Management Agency, 2019

Based on table 1 above, it can be seen that from 2012 to 2018 the number of tourist visits has increased, but in 2019 the number has decreased. From this table, it is necessary to study that the development of the tourist attraction of the Ciletuh Palabuhanratu Geopark must be followed by effective and efficient management and marketing strategies for tourism to the community. If visitors to tourist attractions increase, it will have an impact on increased income so that it is not difficult to cover the costs used for the operation of tourist attractions (Mahendrayani and Suryawan, 2018).

The study in this study discusses the use of SWOT analysis is a process of analyzing marketing strategy planning in tourism awakening. To answer this problem, it is necessary to develop a marketing strategy that can later attract tourists to the Ciletuh Palabuhanratu Geopark. The research analyzes what marketing strategies can be applied in the tourism attraction Geopark Ciletuh Palabuhanratu Sukabumi so that the results can contribute to the tourism operators in the marketing of tourist objects that exist in the area of tourist attraction Ciletuh Palabuhanratu Geopark.

Several aspects matter to the attractiveness of the Ciletuh Palabuhanratu Geopark, from amenities to accessibility which is still lacking. As for the question in the research, this is How the application of the marketing mix Ciletuh Palabuhanratu Geopark tourism increases the number of tourists? And what is the tourism marketing strategy carried out so that managers can increase the number of tourist visits to the Ciletuh Palabuhanratu Geopark?

\section{LITERATURE REVIEW}

1. Marketing Strategy Concept

Tjiptono (2011) suggests that a marketing strategy or marketing strategy is a fundamental and fundamental tool designed to achieve the goals of the company by developing superior and sustainable competitiveness. This is intended to be able to provide the best service for the target targets of the business. A marketing strategy is generally a plan that wants to be carried out in a comprehensive, integrated, and integrated manner in the field of marketing, this is done to guide the activities to be carried out to achieve the marketing objectives of a company. A marketing strategy is a plan that is compiled and concluded based on an analysis of the situation or market conditions for the company's products or services. And it was agreed to be applied in the method of bidding or selling products based on this plan to increase the number of sales and increase profits so that the faster it can also reach ROI. The definition of a marketing strategy or marketing is a comprehensive program from the company to determine the target market and to satisfy consumers. These efforts are carried 
out by building a combination or combination of elements, namely product, promotion, marketing mix, distribution, and price. Kotler (2009) argues that marketing strategy is a series of views and mindsets in marketing that will be used to achieve marketing goals. This mindset contains a detailed strategy regarding the target market or target market, where its position, mix and budget for marketing.

2. Marketing Mix

The marketing mix is a set of tools that marketers use to shape the characteristics of the services offered by customers. These tools can be used to formulate long-term strategies and also to design short-term tactical programs (Tjiptono, 2011). Meanwhile, according to Kotler (2009, p.62), the marketing mix is "a collection of tactical marketing tools controlled by the product, price, place, and promotion needed by the company to produce the response it wants in the target market. Based on the above definition can be concluded that the marketing mix (Marketing Mix) is an element in the marketing interconnected and used by the company in achieving effective marketing both in satisfying the needs and desires of consumers. The marketing mix illustrates the seller's view of the marketing tools used to influence buyers. From the buyer's point of view, each marketing tool must be designed to provide a benefit to the customer and must match the needs and wants. In this paper, we will try to discuss the marketing mix in the service sector. Service marketing requires an expanded marketing mix with the addition of developed elements. Service marketing is said to be a form of product which means any action or action offered from one party to another and is intangible. Meanwhile, this marketing tool is known as the "4P" and was developed into the "7P" which is used very precisely for service marketing. According to Kotler and Keller (2012: 4), $7 \mathrm{P}$ is defined as follows:

a. Product Theory

According to Kotler and Armstrong (2010), a product is always something that can be offered to the market to get attention, buy, own, use, or consume which can satisfy the wants or needs of the wearer. Meanwhile, according to Tjiptono (2011) products are in this context, products can be anything (both physical and non-physical) that can be offered to potential customers to fulfill certain needs and desires.

b. Price Theory

According to Swastha (2009) price is the amount of money (plus some items if possible) needed to get several combinations of goods and services. Meanwhile, according to Kotler (2009) price is the amount of money that must be paid by the customer to obtain a product. Price is an agreement of value which is a requirement for exchange in a purchase transaction. According to Tjiptono (2011), the price is a critical decision that supports the successful operation of an organization profit or non-profit. Price is the only element of the marketing mix that provides income to the organization.

c. Promotion Theory

Kotler (2009) states that promotion is a variety of activities carried out by companies that highlight the features of their products that persuade target consumers to buy them. Meanwhile, according to Siagian (2010), promotion is when a person is transferred from one job to another with greater responsibility, a higher level of the hierarchy of positions, and a greater income. According to Tjiptono (2011), promotion is a form of marketing communication, where companies try to disseminate information, influence /persuade, and/or remind target markets and their products to be willing to accept, buy, be loyal to the products offered by the company concerned.

d. Place Theory

The place is a distribution decision regarding the ease of access to services for potential customers. The consideration in determining the location is that the customer visits the location or the service provider who visits the customer (Tjiptono, 2011). 
Place includes marketing issues such as channel type, exposure, transportation, distribution, and location. A product must be available to consumers when and where consumers want it. Marketers describe this process as a "funnel".

e. People Theory

People are a vital ingredient in the marketing mix. If production can be separated from consumption, as is found in most cases of marketing of manufactured goods, management can usually reduce the direct influence of human resources on the final output received by customers (Tjiptono, 2011). People are all people who play a role in service delivery that can influence consumer perceptions (Zeithaml, Bitner, and Gremler, 2006). People who interact directly with consumers in providing services are an important part of building loyalty. The knowledge and abilities of people who work by company goals are very important assets to achieve success (Grewal and Levy, 2010). People have an important role in the success of a company. People who interact directly with consumers in providing services are an important part of building loyalty. The knowledge and abilities of people who work by company goals are very important assets to achieve success (Grewal and Levy, 2010).

f. Process Theory

According to Payne (2008), states that the process to create and provide services to consumers is a major factor in the marketing mix. In the service management economy, customers will see the service delivery system as part of the service itself. All work activities are part of a process. This process can include various existing mechanisms, such as the existence of service mechanisms, procedures, activity schedules, and routines. According to Kotler (2009), the process here includes how the company serves the demands of each customer. Starting from the consumer ordering (order) until finally, the consumer gets what he wants.

g. Physical Evidence Theory

Physical evidence according to Kotler (2009), namely evidence possessed by service providers that are shown to consumers as a consumer value-added proposal. Physical evidence is a tangible form that is offered to customers. There are no physical attributes for the service, so consumers tend to rely on material cues. Hurriyati (2002) argues that companies through their sales force use three methods in managing strategic physical evidence, namely (1) An attention-creating medium for service companies to differentiate from competitors and make physical facilities as attractive as possible to capture customers from their target market. (2) As a massagecreating medium using symbols or terms to communicate intensively to consumers about the specificity of quality and service products. (3) An effect- creating a uniform dress that is colored, patterned, sound, and design to create something different from the service product offered.

3. Tourist attraction

According to Law Number 10 of 2009 concerning Tourism, Tourism Attraction is anything that has uniqueness, beauty, and value in the form of a diversity of natural, cultural, and man-made wealth that is the target or purpose of tourist visits. A person's decision to take a tour is influenced by the strength of the supporting factors (push factors) and the pull factors (pull factors). These supporting and attracting factors are internal and external factors that motivate tourists to make decisions to travel. The driving factor is generally social-psychological and/or is a person-specific motivation, while the pull factor is the destination-specific attribute. Definition of Tourist Attractions according to the Law of the Republic of Indonesia No. 1010 of 2009 concerning Tourism Chapter I, Article 5, states as follows "tourist attraction" is anything that has uniqueness, beauty, and value in the form 
of a diversity of natural, cultural and manmade wealth that is the target or purpose of tourist visits. Furthermore, Cooper et al (1995: 81) in suggesting that there are 4 (four) components that must be owned by a tourist attraction, namely:

a. Attractions, such as natural attractions, charming local culture, and performing arts.

b. Accessibilities such as road conditions, local transportation, and the existence of public facilities such as terminals.

c. Amenities or facilities (amenities) such as the availability of accommodation, restaurants, and travel agents.

d. Ancillary services, namely tourism organizations required for tourist services such as destination marketing management organizations, conventional and visitor bureau.

\section{RESEARCH METHOD}

The method used in this research is qualitative with a descriptive approach. The data were processed using qualitative descriptive methods, namely data obtained in the field in the form of information, photographs, documents related to the state of the Ciletuh Palabuhanratu Geopark attraction and marketing strategies, including describing the results of interviews with the tourism manager of the Ciletuh Palabuhanratu Geopark. Before analyzing the marketing, strategy using the SWOT approach, what needs to be done first is to identify the marketing mix contained in the Ciletuh Palabuhanratu Geopark. After that, using the SWOT approach, a strategy can be formulated, namely by analyzing the strengths, weaknesses, opportunities, and threats of the Ciletuh Palabuhanratu Geopark tourist attraction. SWOT analysis is the systematic identification of various factors to formulate a company strategy. This analysis is based on the logic that maximizes strengths and opportunities, but at the same time minimizes weaknesses and threats. In the SWOT itself, there is a SWOT matrix, which is that this matrix can clearly describe how the internal strengths and weaknesses of the IFAS (Internal Factor Analysis Summary) faced by the company can be adjusted to the opportunities and external threats of the EFAS (External Factor Analysis Summary) it has.

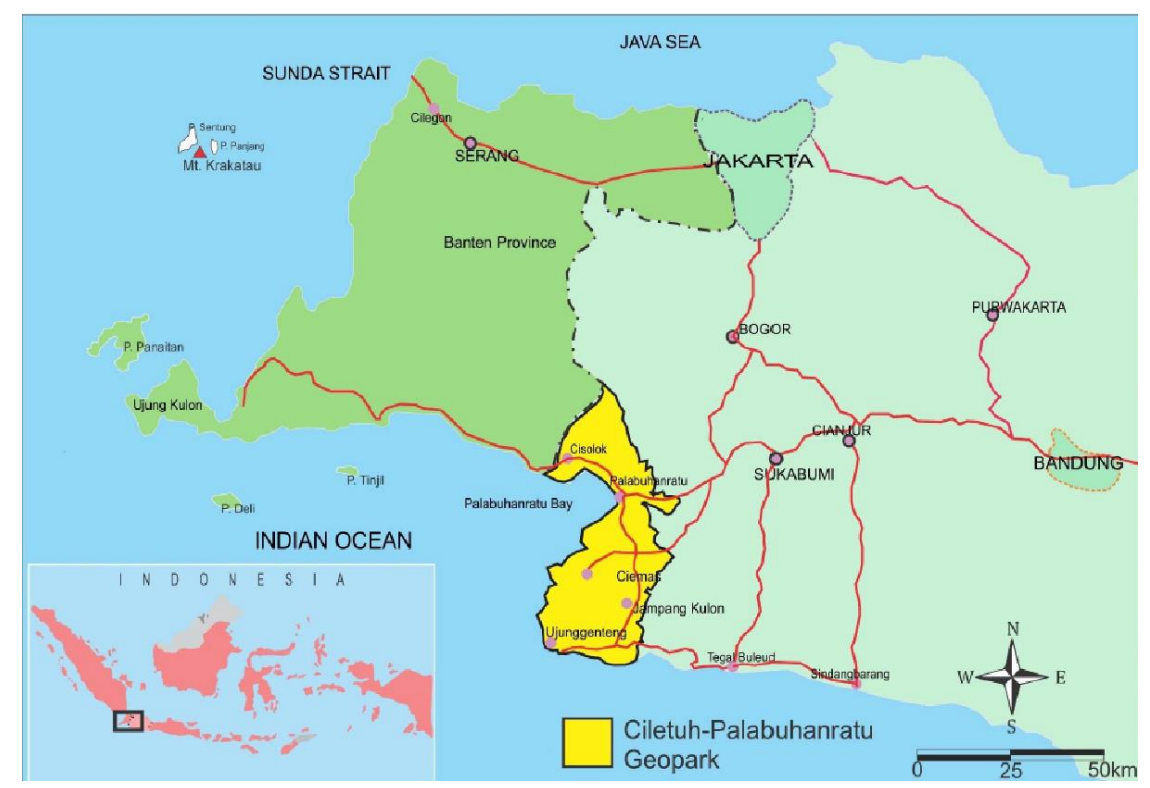

Figure 1. The Location of The Geopark Ciletuh Palabuhanratu Sukabumi

\section{FINDINGS AND DISCUSSION}

The research location (see figure 1) is in the Ciletuh-Palabuhanratu UNESCO Global Geopark (UGG) area of Sukabumi Regency. The area administratively consists of 8 Districts, including Cisolok District, Cikakak
District, Pelabuhan Ratu District, Simpenan District, Waluran District, Ciemas District, Ciracap District, and Surade District. The Ciletuh-Palabuhanratu UGG area is divided into three areas, namely Geoarea Ciletuh, Geoarea Simpenan, and Geoarea Cisolok. 


\section{Profile Kawasan Geopark Ciletuh- Palabuhanratu}

Geopark Ciletuh Palabuhanratu is one of the oldest rock gardens on the island of Java. However, this area was only opened to the public and became a tourist spot in 2015. Moreover, at this time the Ciletuh Geopark Tourist Area has been inaugurated by UNESCO as one of the world heritages sites. Ciletuh Geopark is an area consisting of mountains and beaches in the ancient rock composition. The rock appeared on the surface because it was deposited in the ocean trench as a result of the submergence of the oceanic plate under the continental plate during the Cretaceous Period, 50 - 65 million years ago. The Ciletuh-Palabuhanratu Geopark has an area of 126,100 hectares or 1,261 km2. Covers 74 villages, in eight sub-districts namely Ciracap, Surade, Ciemas, Waluran, Simpenan, Palabuhanratu, Cikakak, and Cisolok Districts, which are divided into three areas, namely: Geo area Ciletuh, Geo area Simpenan, and Geo area Cisolok.

The Ciletuh-Palabuhanratu Geopark also includes the Cibanteng, Tangkubanparahu, Sukawayana Nature Reserve Areas; Cikumpang Wildlife Reserve Area; and the Sukawayana Nature Park, managed by the West Java Natural Resources Conservation Center; an integrated military training area managed by KOSTRAD; Turtle conservation area in Pangumbahan; and the air force training area at Tanjung Ujunggenteng; shrimp ponds in Mandrajaya and Ujunggenteng and batik villages in Purwasedar (Rosana, et al., 2015).

Access to Geo area Ciletuh can be reached by road from Jakarta or Bandung to Tamanjaya Village in Ciemas District via the city of Palabuhanratu. The Ciletuh Geopark Tourism Area can be reached about 8 hours from the center of Jakarta and can be passed by private vehicles. Travel to the geopark area can also be by sea by using a motorboat from the Palabuhanratu pier to Palampang Beach in Ciwaru Village. Ideally, when visiting the Ciletuh Geopark Tour, it will take 3-4 days if you want to enjoy most of the natural attractions in the Geopark. But if visitors may only have limited time, visitors can still visit several main locations in the Ciletuh Geopark which can be reached within one day. For example, such as Panenjoan, Palangpang Beach, Cimarinjung waterfall, Awang waterfall, Sodong waterfall, and Puncak Darma.

Ciletuh Geopark is a tourist spot that has a complete variety of tourist attractions on the island of Java and offers views of the expanse of sea rocks and several beautiful mountain waterfalls (Nandi and Malik, 2019). In this Ciletuh Geopark, visitors can enjoy the natural scenery offered. Starting from mountains, waterfalls, beaches, peaks, and beautiful landscapes with a sea background. In addition, geological sites in Geopark Ciletuh Palabuhanratu receive provincial-level protection through Regional Regulation of West Java Province Number 2 of 2002 concerning Protection of the Geological Environment and Decree of the Regent of Sukabumi Number 556/ Kep.555Disparbudpora/2015 concerning the designation of the Ciletuh Geopark area. Most of the geological sites are part of the Cibanteng Nature reserve and Cikumpang Wildlife Reserve which are managed by the West Java BKSDA. Currently, these geological sites are also being proposed as Geological Nature Reserve Areas (KCAG) to the Geological Agency, Ministry of Energy, and Mineral Resources. Geological sites in the National Geo area of ciletuh Palabuahanratu can be grouped based on their types, namely: Waterfalls: landscapes, small islands, rocks, sea caves, rare rocks and fossils, beaches, geysers.

\section{Visitor Profiles and Characteristics}

Based on the search results of documentation and information provided by the manager, it is found that, in general, a profile is something that has not changed for quite a long time. Gender, age, education, and domicile can be categorized as profiles. While the characteristics of visitors in this study are differentiated based on the tourist attractions that are frequently visited, the time spent traveling, the length of time spent traveling to the information obtained about GCP Tourism.

GCP Tourism Visitors are dominated by Jabodetabek visitors, this may be due to tourist locations that are strategic enough for travelers 
who are domiciled in the Capital City and around and do not require sea or air transportation. In addition, based on the age of visitors, the range is 21-30 years. This is following the segmentation of the GCP Tourism management itself, which is intended for young to adult age, and the possibility of using the internet or social media is dominated by 21-30 years old.

Tourism nature is optional tours of the most frequented by tourists, this is following GCP travel to spoil the visitors with its natural wealth. Most of the tourists know GCP Tourism information from the internet. This can affect experiential marketing, in recommending tourist attractions to friends/relatives. Meanwhile, the time used for traveling is taking time off from work and national holidays because most of them are students and employees, so the information shows that students and employees cannot take too long vacations.

\section{Marketing Mix}

The arrival of tourists to the tourist attraction of the Geopark Ciletuh Palabuhanratu cannot be separated from the information they get from the mass media and promotions carried out by the manager. Marketing strategy is important in marketing tourism products because tourists are a potential market for the sustainability of a place's tourist attraction. The marketing strategy analysis is carried out through:

1. Product (Products)

In marketing services, especially tourism, a product is closely related to tourist attraction. In this case, the product offered by the Ciletuh Geopark tourist attraction is not only a waterfall (curug) but the natural beauty offered varies from natural diversity to cultural diversity. Examples such as the beach, Geyser, Cave, National park life sanctuary, nature reserves, forest conservation, conservation of sea turtles, as well as the cultural diversity that is unique like a village cultural (traditional kasepuhan), sites archeology historic buildings (traces of colonialism), traditional arts and the village of batik.

2. Price (Price)
To enter the Ciletuh Palabuhanratu Geopark attraction, the manager does not set any price rates, within the Ciletuh Geopark area there are several tourist attractions, and they are all still free, but there are some of them that set quite cheap rates of only around Rp. 3000 - Rp. 10,000 per person and that is the price which is still quite affordable for a tourist attraction in the same class as the Ciletuh Palabuhanratu Geopark.

3. Place (place)

Location is important in tourism marketing. Because the location of the existence of the tourist attraction becomes attractive and the location becomes one of the distribution channels that cannot be moved and must be enjoyed at the place of the tourist attraction. The location of the Ciletuh Geopark tourist attraction is in the Ciletuh-Palabuhanratu UNESCO Global Geopark (UGG), Sukabumi Regency. The distance from the provincial capital is about $187.9 \mathrm{~km}$ or can be reached by vehicle in about 6 hours and the distance from the national capital is about 4 hours. This is the reason why many tourists come from the capital city or Jabodetabek because the distance to the location of tourist attractions is closer.

4. Promotion (Promotion)

To introduce and bring visitors to the tourist attraction of the Ciletuh Palabuhanratu Geopark, managers need various promotions so that prospective visitors first know and know about the tourist attraction of the Ciletuh Palabuhanratu Geopark. The forms of promotion used are: (1) Advertising is done by making regular brochures, collaborating with several travel applications, and promoting in the form of advertisements in various travel magazines on several airlines. (2) personal selling, one of which is by holding a tourist exhibition at home and abroad. (3) Public Relations by inviting the media or press release related to the big moment that occurred at the GCP Tourist Attraction, supporting television programs that wish to cover tourism objects at GCP. (4) Sales Promotion carried out by GCP managers is 
by providing tour packages with lodging at residents' homes with different classifications which are commonly called homestays. (5) Direct marketing is carried out through promotion through the official website managed by GCP. On the website, there are detailed information and call center services that can help people ask questions about GCP tours.

5. People (People)

Another thing that supports the tourism marketing strategy is human, tourism actors are all parties who play a role and are involved in tourism activities. As for those who become tourism actors, namely tourists or consumers who use tourism products, service providers, government, local people in the GCP tourist attraction, this is in line with what Yazid (2005: 56) said that people are all actors who play a role in service presentation so that it can influence buyers' perceptions. For GCP employees, consisting of managers in several geo sites, tour guides, hotel/lodging managers, restaurant employees, the employees' rights and obligations are implied, the appearance of employees who influence the successful delivery of services from these elements to tourists.

6. Process (Process)

The form of the process carried out by the tourist attraction of the Ciletuh Palabuhanratu Geopark includes the process of delivering information to tourists and the process of service to tourists. According to Tjiptono (2011: $146)$, the process concerns the way companies work in providing services to consumers in providing products to consumers. The process of GCP tourist attraction is still lacking, this is reflected in the sub-optimal management system throughout the geo site; with the GCP area covering a total of 8 districts, it means that it is also supported by the potential and diversity of types of tourism that require attention in management so that it will have an impact on increasing the number of tourist visits. low quality of service for tourists, low public awareness of the importance of tourism development, inadequate infrastructure, and so on.
7. Physical evidence (Physical Infrastructure) The tourist attraction area of GCP has a variety of natural resources that are very potential as a tourist attraction. Natural physical environmental conditions make this tourist dance attractive to tourists because its location is far from urban areas making the air environment cool, full of trees that are still beautiful and green. There is a potential physical condition of ni ranging from waterfalls, nature reserves, small islands, geological and biological diversity, and culture. There are at least 8 waterfalls that can be visited, including Curug Luhur (Cigangsa), Puncak Jeruk Waterfall in the Ciletuh and Mekarjaya Rivers, Cikaret Waterfall in the Cikaret Mekarjaya River, Curug Puncak Manik Ciletuh River which borders Tamanjaya and Cibenda Villages, Curug Awang River Stream Ciletuh Tamanjaya, Cikanteh Waterfall Located in Ciwaru Village, Sodong Waterfall is in Ciwaru Village and Cimarinjung Waterfall is in Ciemas Village near the Palangpang Beach. For the sustainability of GCP's tourist attraction so that it continues to exist and is in demand by tourists, the manager should optimize his attention to the tourist attraction, including by improving public facilities, improving accessibility to these tourist attractions, so that tourists who visit are comfortable and interested in returning data to the place.

\section{SWOT Analysis of Tourism Marketing at Ciletuh Palabuhanratu Geopark}

SWOT analysis is an analysis that explains the factors that are the strengths, weaknesses, opportunities, and threats that are contained in the tourist attraction of GCP.

1. Internal Factors

a. Strengths (Strength)

The tourist attraction of GCP is one of the mainstay tourist destinations in Sukabumi Regency. In this area, there are various types of attractions that can be explored by tourists, from physical diversity to the cultural diversity of the people united into an interesting combination. Many forms of diversity 
are not shared by other tourist destinations. The forms of diversity are (1) Geological diversity, for example, such as Landscape, Rare and Fossil Rock Types, Unique Rocks, Small Islands, Caves, Waterfalls, Beaches, Geysers. (2) K eanekaragaman biodiversity (biological diversity), co ntohnya such as National Parks, Wildlife, Nature Reserves, Nature Parks, Forest Conservation, the Turtle Conservation, agriculture, horticulture, cultivation of shrimp and lobster, Livestock, Aquaculture eels. (3) Cultural diversity, for example, such as a cultural village (adat Kasepuhan). Archaeological Sites, Historical Buildings (Traces of Colonialism), Art, Traditions, Legends / Myths, Batik Village. These three things are mandatory elements in the formation of a geopark. With good management, it is not surprising that one day the Ciletuh Palabuhanratu geopark will become one of the attractions that deserve to be reckoned with for West Java tourism.

b. Weaknesses (Weakness)

The problems that arise in the context of developing the GCP tourist area are one of the weaknesses in the GCP tourist attraction, including the low accessibility to and within the GCP area; although the government always tries to improve the road through casting, especially the access from Bogor to Sukabumi Regency causes congestion to the tourist route. This congestion problem has an impact on inconvenience for tourists who come and for business actors around the route. The low quantity and quality of tourism anesthesia (public infrastructure, public facilities, and tourism facilities). Because, there are several obstacles in the development of tourism, including the low quality of service for tourists, low public awareness of the importance of tourism development, inadequate infrastructure, and so on. Therefore, there are many things that the government must do, such as empowering the community to improve service quality and also increasing public awareness regarding the Ciletuh-Palabuhanratu Geopark tourism, and infrastructure improvements are needed. Apart from the work above, there are still many things that must be done by the government as the main substation to make the Ciletuh-Palabuhanratu Geopark a tourism worth visiting.

2. External Factors

a. Opportunities

Nature tourism with the concept of natural beauty (back to nature) is a tourism trend that is currently developing. This can encourage tourism managers to compete to provide the best service to tourists so that the products offered can attract as many tourists as possible. Based on data obtained from the manager, most tourists come to GCP tourist attractions intending to have a vacation. Most of them get information from the internet apart from relatives and friends. The presence of automatic economic tourists at GCP has an impact on the welfare of the surrounding community. Entrance tickets to the GCP tourist area which are implemented by the manager of the GCP tourist dance attraction are very affordable, there are even some tourist attractions that are free of charge or free, tourists are free to enter the area free of charge. This, when compared to other tourist objects, is still very far away, because in other places tourists can be charged expensive fees to enter similar tourist areas. Promotions carried out by GCP have begun to appear, namely with the existence of tourism events that have reached abroad, such as tourism fairs, or promotions through advertisements through mass media or brochures that are distributed in public places such as airports, stations, and terminals where tourists arrive. In addition, there is a form of tourism development cooperation between the university and 
the provincial government as the main substation in the development of GCP tourist attractions.

b. Threats

The challenge faced by GCP is that the location of this tourist attraction is far from the city center, this is a challenge for the manager, how to attract tourists to visit this place. In addition, the waste problem is still a work that must be completed by the management together with the community and related parties, so that the beauty of the GCP tourism dance is maintained. Low public awareness of the importance of tourism development is a challenge for the advancement of GCP's tourist attraction

\section{Marketing Strategies That Must Be Implemented to Increase the Number of Tourist Visits to the Tourist Attractions of the Ciletuh Palabuhanratu Geopark}

Based on the IFAS and EFAS analysis, strategic factors are the dominant factors in the form of strengths, weaknesses, opportunities, and threats that influence existing conditions and situations and can provide positive benefits to the environment. Internal environmental analysis (IFAS) to determine possible strengths and weaknesses. This strategy can see tourism problems in the future. Meanwhile, external environmental analysis (EFAS) is to determine possible opportunities and threats. This strategy can spot future visitor problems.

\section{SO Strategy}

This strategy uses the company's strengths to take advantage of the opportunities that exist. The strategy that can be applied in marketing the Ciletuh Palabuhanratu Geopark Tourist Attraction is by attractive packaging of tourism products and services. This strategy is expected when tourists visiting the Ciletuh Palabuhanratu Geopark get a complete experience while in the tourist destination visited until they return to their place of origin. Managers can make natural and cultural tourism as attractive as possible so that tourists want to come to visit the Ciletuh Palabuhanratu Geopark Tourist Attraction. Another thing that needs to be considered is the tourist service, which is a facility that can be used by tourists so that tourists who visit feel at home and give satisfaction so that they think of being able to return to these tourist attractions.

2. ST Strategy

This strategy uses strength to overcome threats. This strategy is carried out by embedding an image (image) on a very important tourist destination. A destination that has a good image has certainly satisfied its consumers. The Ciletuh Palabuhanratu Geopark area which is a tourist attraction has an image as a tourist destination that has been confirmed as a UNESCO Global Geopark and has become a world heritage, for that it is necessary to instill a good image of this destination. Strategies that can be applied by combining the marketing mix with natural and cultural tourism that is owned. Another thing that needs to be considered for managers of tourist attractions and the surrounding community is to be able to protect their environment by maintaining cleanliness, natural beauty so that tourists who come to the Ciletuh Geopark Tourist Attraction feel comfortable and are not disturbed by garbage or dirty environments. For this reason, the management together with related parties can educate and empower the surrounding community so that they are more aware and care about their environment.

3. WO Strategy

This strategy is designed by trying to minimize weaknesses to take advantage of existing opportunities. Strategies that can be implemented through increased promotion. Promotion of the tourist attraction of the Ciletuh Palabuhanratu Geopark is continuously carried out so that the number of tourists continues to increase, a lot of media is used to promote the Ciletuh Palabuhanratu Geopark, from advertising, public relations, personal selling, sales promotion, and direct marketing. With the right marketing process with a clear target market, the tourist attraction will be crowded with tourists. The popularity of a tourist spot 
among tourists depends on the marketing process. In its implementation, tourism marketing must show an advantage and uniqueness of the tourist attraction and the sustainability of the promotion must be done as optimally as possible. In marketing the tourist attraction of the Ciletuh Palabuhanratu Geopark to be better known, the manager must be more active in collaborating with related stakeholders.

4. WT Strategy

This strategy is designed to minimize weaknesses by avoiding threats that will arise. The strategy used in the WT strategy is a community empowerment strategy and a strategy of building commitment and cooperation with stakeholders. In managing tourism activities, it cannot be done alone, this activity requires related parties to run smoothly. The implementation of the tourism system can run well if all components in tourism are united and support each other. The stakeholders involved such as the government, private sector, and community organizations are important elements that must work together to fix all matters relating to facilities and infrastructure in the sustainability of tourism. The government is the party that provides planning policies in tourism development by building and providing supporting infrastructure for tourism activities, improving the quality of human resources who work as workers in tourist destinations. Furthermore, the private sector as a business actor has a role in providing tourism support facilities. Tourism requires many supporting facilities such as restaurants, accommodation, travel agents, transportation, and others (Yoeti, 1996). Whereas the community as owners and managers can become part of tourist attractions to attract tourists by introducing culture and daily habits that are the uniqueness and characteristics of tourist objects. Infrastructure development is something that must be done in developing the tourist attraction of the Ciletuh Palabuhanratu Geopark. This aims to improve services to tourists. Infrastructure development is carried out to make it easier for tourists who want to visit so that this is intended to increase the number of visitors. Another problem that needs to be addressed is the low level of public awareness of the importance of tourism development. In the Ciletuh Palabuhanratu Geopark area, many villages have the potential to be developed, therefore people whose areas have the potential to become tourist sites need to be educated and fostered so that they will be ready to become tour guides in their environment. For this reason, the role of the government and non-governmental organizations is to play a role in fostering and educating the public, so that the potential that exists in tourism locations can develop optimally.

\section{CONCLUSIONS}

From the results of the analysis that has been carried out, there are several limitations in the development of the tourist attraction of the Ciletuh Palabuhanratu Geopark which are still limited in conducting promotions and there is still a lack of adequate infrastructure. Therefore, by analyzing the strengths, weaknesses, opportunities, and threats faced by the tourist attraction of the Ciletuh Palabuhanratu Geopark by using SWOT analysis, a marketing strategy that can be applied is obtained, namely strategies for packaging attractive tourism products and services, strategies for building commitment and cooperation. with stakeholders, strategies to instill a brand image in the minds of visitors/build a place identity (Positioning), strategies to increase promotion. The strategies that have been formulated can be applied in marketing the Ciletuh Palabuhanratu Geopark Tourist Attraction, as well as maximizing all the potential to bring in more tourists visiting this attraction.

\section{REFERENCES}

Cooper, dkk. (1995). Tourism, Principles and Practice. Prentice Hall, Harlow.

Goeldner, C. R., and Ritchie, J. R. B. (2003). Tourism: Principles, Practices, Philosophies, 9th NY: John Wiley \& Sons, Inc 
Grewal, Dhruv, \& Michael, L. (2010). marketing (2nd ed.). New York: McGraw Hill.

Henderson, Joan C. (2010). Tourism Management and The Southeast Asian Economic and Environmental Crisis: A Singapore Perspective. In Journal Managing Leisure, Vol 4, page 107-120. Taylor \& Francis Online. https://doi.org/10.1080/1360671993758 87

Hurriyati, R. (2002). Bauran pemasaran dan loyalitas konsumen. Bandung: Alfabeta

Kartika, T., Ruskana, R., Fauzi, M, I., (2018). Strategi Pengembangan Daya Tarik Dago Tea House Sebagai Alternatif Wisata Budaya di Jawa Barat. STIEPAR YAPARI Bandung.

Kotler, P. \& Keller, K. L. (2012). Marketing management (14th ed.). United States of America: Pearson.

Kotler, P. (2009). Manajemen pemasaran. Jakarta: Erlangga.

Kotler, P., \& Armstrong, G. (2010). Principles of marketing. (13th ed.). United States of America: Pearson.

Mahendrayani dan Suryawan. (2018). Strategi Pemasaran Daya Tarik Wisata Untuk Meningkatkan Jumlah Kunjungan Wisatawan Ke Daya Tarik Wisata Sangeh Kabupaten Badung Provinsi Bali. Fakultas Pariwisata, Universitas Udayana

Nandi \& Y. Malik, (2019), Visual landscape analysis of coastal tourism potential in Geopark Ciletuh-Palabuhanratu Indonesia, Scientific Bulletin of Naval Academy, Vol. XXII, pg.46-52. doi: 10.21279/1454-864X-19-I2-005

Payne, A. (2008). Pemasaran Jasa, The Essence of Service Marketing, Penerbit Andi,

Rahim, F. (2012). Pedoman Pokdarwis. Jakarta: Direktur Jenderal Pengembangan Destinasi Pariwisata Kementerian Pariwisata dan Ekonomi Kreatif.
Rangkuti, F. (2006). Riset pemasaran. (5th ed.). Jakarta: Gramedia Pustaka Utama.

Ritonga, H, M., Setiawan, N., Fikri, M, E., Ritonga, C, P, M., Hakim, T., Sari, M, M., Rossanty, Y., and Nasution, M, D, T, P., (2018). Rural Tourism Marketing Strategy and Swot Analysis: A Case Study of Bandar Pasir Mandoge SubDistrict in North Sumatera., in Journal International Journal of Civil Engineering and Technology (IJCIET), Vol. 9. Universitas Pembangunan Panca Budi, North Sumatera, Indonesia.

Swastha, Basu DH., (2006). Manajemen Penjualan, Penerbit BPFE, Yogyakarta

Sweeney, et. al., (1998). Mistletoe lectin I forms a double trefoil structure, FEBS Letters.

Tam, Jackie L. M dan Y. H. Wong, (2001). Interactive Selling: a dynamic Framework for Services, Journal of Service Marketing. Vol. 5 No.5

Tjiptono, F. (2011). Pemasaran jasa. Malang: Bayumedia Publishing.

Yazid. (2003). Pemasaran Jasa, Edisi Kedua, Ekonisia Fakultas Ekonomi UII, Yogyakarta.

Yoeti, O.A. (1996). Pengantar Ilmu Pariwisata. Bandung: Angkasa

Zaenuri, M. (2014). Mengelola PariwisataBencana: Perlunya Perubahan Paradigma Pengelolaan Pariwisata Dari Adaptive Governance Menuju Collaborative Governance. Universitas Muhammadiyah Yogyakarta

Zeithaml, A., A. Valerie., Parasuraman., and L. Berry. (2009). Services marketing integrating customer focus across. New York: Prentice Hall Mc. Graw Hill

Zeithaml, V.A., Bitner, M.J. \& Gremler, D.D. (2006). Service marketing. 4 th edition. New York: The MCGraw-Hill Companies, Inc. 